\title{
PENGARUH PEMBIAYAAN MUDHARABAH TERHADAP PERTUMBUHAN LABA BANK UMUM SYARIAH (BUS) DI INDONESIA TAHUN 2014-2016
}

\author{
Falahudin $^{\mathrm{a} 1}$, Manis Taqna ${ }^{\mathrm{a} 2}$ \\ ${ }^{a}$ Fakultas Ekonomi dan Bisnis Universitas Malikussaleh \\ 1Corresponding author: falahudin@unimal.ac.id \\ 2 manistaqna1996@yahoo.com
}

\section{ARTICLE INFORMATION ABSTRACT}

\section{Keywords:}

Mudharabah and Profit Financing
The research aims to determine whether mudharabah financing affects the profit of Islamic Commercial Banks in Indonesia in the year 2014-2016. This research uses seconday data from 2014-2016. This research employ simple linear regression to analize data. The research results show that mudharabah $(X)$ financing has a positive and significant effect on Profit of Islamic Commercial Banks (Y).

\section{PENDAHULUAN}

Suatu perusahaan pada tahun tertentu bisa saja mengalami pertumbuhan laba yang cukup pesat dıbandingkan dengan rata-rata perusahaan. Akan tetapi untuk tahun-tahun berikunya perusahaan tersebut bisa saja mengalami penurunan laba. (Karim, 2004). Perbankan syariah menjadi salah satu lembaga keuangan yang berfungsi sebagai lembaga perantara keuangan yang menghimpun dana dari masyarakat yang kelebihan dana dan menyalurkannya kepada pihak-pihak yang kekurangan dana. Perbankan syariah pada saat ini masih berada pada tahap perkembangan dengan tetap meningkatkan nasabahnya. Dengan peningkatan jumlah nasabah maka akan meningkatkan laba dari perbankan syariah tersebut. Salah satu cara yang dapat dilakukan untuk mendorong perkembangannya tersebut adalah melalui pembiayaan yang diberikan oleh perbankan syariah (Muhammad, 2005). Berikut ini merupakan tabel 1 yang menunjukkan tingkat Pertumbuhan Laba Bank Umum Syariah di Indonesia dari Tahun 2014 sampai dengan 2016

\section{Tabel 1}

Pertumbuhan Laba dan Tingkat Pembiayaan Mudharabah Bank Umum Syariah (BUS)

\section{di Indonesia}

\begin{tabular}{|c|c|c|c|c|c|c|c|}
\hline \multirow[t]{2}{*}{ No } & \multirow{2}{*}{$\begin{array}{l}\text { Bank Limum Syariah } \\
\text { (BUS) }\end{array}$} & \multicolumn{3}{|c|}{$\begin{array}{l}\text { Rertumbuthan Laha dalam } \\
\text { persen (\%) }\end{array}$} & \multicolumn{3}{|c|}{$\begin{array}{l}\text { Pembiavash } \\
\text { Madharabah (\%) }\end{array}$} \\
\hline & & 2014 & 2015 & 2016 & 2014 & 2015 & 2016 \\
\hline 1. & $\begin{array}{l}\text { PT. Bank BN } \\
\text { Syariah }\end{array}$ & 12,00 & 12,34 & 12,53 & 0,36 & 0,21 & $-0,06$ \\
\hline 2. & $\begin{array}{l}\text { PT. Bank BRI } \\
\text { Syariah }\end{array}$ & 7,94 & 11,72 & 12,04 & $-0,06$ & 0,23 & 0,13 \\
\hline 3. & $\begin{array}{l}\text { PT. Bank Mramalat } \\
\text { Indonesia }\end{array}$ & 17,89 & 18,13 & 18,20 & 0.49 & $-0,49$ & $-0,28$ \\
\hline
\end{tabular}

\begin{tabular}{|c|c|c|c|c|c|c|c|}
\hline 4. & $\begin{array}{l}\text { PT. Bank Syariah } \\
\text { Mandiri }\end{array}$ & 24,52 & 26,39 & 26,51 & 0.93 & $-0,05$ & 0,08 \\
\hline 5. & $\begin{array}{l}\text { PT. Bank Syariah } \\
\text { Bukppin }\end{array}$ & 22,88 & 24,05 & 24,21 & 2.93 & $-1,88$ & $-0,16$ \\
\hline 6. & PT. BCA Syariah & 23,28 & 23,88 & 24,33 & -0.06 & 0,05 & 0,54 \\
\hline 7. & $\begin{array}{l}\text { PT. Bank Victoria } \\
\text { Syariah }\end{array}$ & 23,69 & 23,90 & 23,64 & 0.48 & $-1,12$ & 1,48 \\
\hline 8. & $\begin{array}{l}\text { PT. Bank Mega } \\
\text { Syariah }\end{array}$ & 16,67 & 16,32 & 16,53 & 0,23 & $-1,85$ & 1,60 \\
\hline 9. & $\begin{array}{lll}\text { PT. Bank } & \text { Jabsr } \\
\text { Banten Syariah } & \end{array}$ & 15,76 & 15,80 & 19,84 & $-0,59$ & 0,27 & $-0,43$ \\
\hline 10. & $\begin{array}{l}\text { PT. Maybank Syariah } \\
\text { Indonesia }\end{array}$ & 10,93 & 12,59 & 12,00 & $-2,65$ & 0,16 & $-0,42$ \\
\hline 11. & $\begin{array}{l}\text { PT. Bank Panin } \\
\text { Syariah }\end{array}$ & 18,07 & 17,79 & 16,79 & 1,79 & 0,184 & $-0,55$ \\
\hline 12. & PT. BTPN Syariah & 11,42 & 12,04 & 12,93 & $-2,92$ & 0,38 & 0,38 \\
\hline
\end{tabular}

Sumber: Laporan Keuangan BUS, 2017

Dapat dilihat bahwa data pertumbuuhan labaa Bank Umum Syariah (BUS) di Indonesia sepanjang tahun penelitian yaitu dari tahun 2014 sampai dengan tahun 2016. Pada tahun 2014 dapat kita ketahui dari tabel diatas bahwa pertumbuhaan labaa tertinggi itu tejadi pada PT. Bank Syariah Mandiri yaitu sebesar 24,53\%. Sedangkan pertumbuhan laba terendah pada tahun 2014 yaitu terjadi pada PT. Bank BRI Syariah yaitu sebesar 7,94\%. Pada tahun 2015 dapat kita lihat dari tabel diatas bahwa pertumbuhan laba tertinggi itu terjadi pada PT. Bank Syariah Mandiri yaitu sebesar 26,39\%. Sedangkan pertumubahan laba terendah pada tahun 2015 terjadi pada PT. Bank BRI Syariah yaitu sebesar 11,72\%. Pada tahun 2016 pertumbuhan laba tertinggi terjadi pada PT. Bank Syariah Mandiri yaitu sebesar $26,51 \%$. Dan pertumbuhan laba terendah pada tahun 2016 terjadi pada PT. Maybank Syariah Indonesia yaitu sebesar $12,00 \%$. 
Fenomena angka pertumbuhan laba dan pembiayaan mudharabah bagi bank umum syariah yang mengalami kenaikan maupun penurunan tersebut terjadi karena kurangnya efektifitas bank umum syariah sebagai lembaga intermediasi. (Muhammad, 2005)

Adapun yang menjadi tujuan dalam penelitian ini adalah untuk mengetahui pengaruh pembiayaan mudharabah berpengaruh terhadap pertumbuhan laba Bank Umum Syariah (BUS) di Indonesia Tahun 20142016.

\section{TINJAUAN TEORITIS}

\section{Pengertian Laba}

Menurut (Kasmir, 2012)berpendapat bahwa Laba disebut juga dengan keuntungan yang merupakan salah satu tujuan utama perusahaan dalam menjalankan kegiatan usahanya.

\section{Bank Umum Syariah}

Menurut (Ismail, 2011)dalam bukunya menjelaskan Bank Umum Syariah (BUS) adalah bank yang dalam aktifitasnya melaksanaakan kegiatan usaha sesuai dengan prinsip syariah dan melaksanakan kegiatan lalu lintas pembayaran.

\section{Faktor-Faktor yang Mempengaruhi Pertumbuhan Laba}

Menurut Sudarsono (2007) Pertumbuhan laba dipengaruhi oleh beberapa faktor antara lain:

a. Besarnya Perusahaan

Semakin besar suatu perusahaan, maka ketepatan pertumbuhan laba yang diharapkan semakin tinggi. Hal ini disebabkan besaran perusahaan karena skala ekonomi yang berbeda-beda. Skala ekonomi yang tinggi menyebabkan perusahaan dapat menghasilkan produk dengan tingkat biaya rendah. Tingkat biaya rendah merupakan unsur untuk mencapai laba yang diingikan sesuai standar yang dituangkan dalam bentuk ramalan.

b. Umur perusahaan.

Perusahaan yang baru berdiri kurang memiliki pengalaman dalam mengingkatkan laba, sehingga ketepatannya masih rendah.

c. Tingkat leverage

Bila perusahaan memiliki tingkat hutang yang tinggi, maka manajer cenderung memanipulasi laba sehingga dapat mengurangi ketepatan pertumbuhan laba. Salah satu kewajiban manajer adalah mengatur resiko. Jadi manajer melakukan apa saja untuk mengurangi resiko Tingkat leverage merupakan salah satu hal yang mencerminkan resiko. Risiko tingkat leverage dapat tercermin dari likuiditas yang dimiliki. Jadi manajer memperhatikan aspek ini dalam melakukan peramalan laba. d. Tingkat penjualan.

Tingkat penjualan di masa lalu yang tinggi, semakin tinggi tingkat penjualan di masa yang akan datang sehingga pertumbuhan laba semakin tinggi.

e. Perubahan laba masa lalu

Semakin besar perubahan laba masa lalu, semakin tidak pasti laba yang diperoleh di masa mendatang. Fator ini mempunyai dampak signifikan terhadap laporan keuangan, termasuk ramalan perubahan laba. Oleh karena itu auditor harus menjamin bahwa informasi keuangan yang disajikan telah sesuai dengan pedoman penyajian laporan keuangan.

\section{Pembiayaan Mudharabah}

Menurut Qordhawi(1997)Pembiayaan mudharabah secara tidak langsung adalah bentuk penolakan terhadap sistem bunga yang diterapkan oleh bank konvensional dalam mencari keuntungan. Karena itu pelarangan bunga ditinjau dari ajaran Islam merupakan perbuatan riba yang diharamkan dalam Al-Qur'an, sebab larangan riba tersebut bukanlah meringankan beban orang yang dibantu dalam hal ini nasabah/mudharib tetapi merupakan tindakan yang memperalat dan memakan harta orang lain tanpa melalui jerih payah dan berisiko serta kemudahan yang diperoleh orang kaya di atas kesedihan orang miskin.

Menurut Antonio (2001) Akad mudharabah adalah akad kerja sama antara dua belah pihak, yang mana pihak pertama (shahibul maal) menyediakan seluruh modalnya, sedangkan pihak yang lain menjadi pengelola (mudharib). Keuntungan usaha secara mudharabah dibagi menurut kesepakatan yang dituangkan dalam kontrak, sedangkan apabila mengalami kerugian akan ditanggung oleh pemilik modal selama kerugian tersebut bukan akibat kelalaian dari si pengelola. Akan tetapi, jika kelalaian tersebut diakibatkan oleh kecurangan atau kelalaian si pengelola, maka harus bertanggung jawab atas kelalaian tersebut.

\section{Hubungan Pembiayaan Mudharabah Terhadap Pertumbuhan Laba}

PembiayaanMudharabah mencerminkan skema investasi yang pengelolaanmodalnya berasal penuh dari investor yang diberikan kepada pengelola usaha.Dalam hal ini, investor memberikan sejumlah modal usaha kepada pengelolausaha dengan adanya perjanjian pembagian keuntungan. Keuntungan yangdiperoleh melalui prinsip mudharabah dibagi menurut kesepakatan yangtertuang dalam kontrak, sedangkan kerugian di tanggung oleh pemilik modal(shohibul maal) selama kerugian tersebut bukan merupakan kelalaian daripengelola modal (mudharib). 
Hubungan pembiayaan mudharabah terhadap laba yaitu semakin banyak nasabah yang menggunakan produk pembiayaan mudharabah, maka akan meningkatkan pertumbuhan laba. Hal ini seperti yang di kemukan oleh hasil penelitian dari Miftahurrohmah (2014) menyatakan bahwa simpanan dalam bentuk pembiayaan mudharabah berpengaruh positif terhadap laba. Meningkatnya simpanan dalam bentuk pembiayaan mudharabah disebabkan pengelolaan yang baik oleh bank dengan memberikan pembiayaan kepada nasabah. Semakin banyak pembiayaan dalam bentuk simpanan mudharabah disalurkan akan meningkatkan laba perbankan syariah.

\section{Kerangka Konseptual}

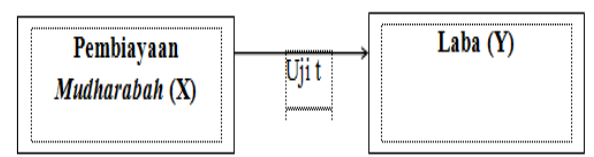

\section{Gambar 1}

\section{Kerangka Konseptual}

Penulis ingin mengetahui Pengaruh Pembiayaan Mudharabah (X) Terhadap Pertumbuhaan Laba (Y) Bank Umum Syariaah di Indonesia Tahun 2014-2016.

\section{Hipotesis}

$\mathrm{H}_{\mathrm{O}}$ : Pembiayaan Mudharabah tidak berpengaruuh terhadap Laba Bank Umum Syariah.

$\mathrm{H}_{\mathrm{a}}$ : Pembiayaan Mudharabah berpengaruuh terhadap Laba Bank Umum Syariah.

\section{METODE PENELITIAN}

Objek penelitian adalah Laba Bank Umum Syariah dan pembiayaan mudharabah Baank Umum Syariah. selama 3 tahun yaitu 2014-2016 dengan pengolahan data secara tahunan.

\section{Metode Analisis Data}

Metode regresi yang digunakan adalah regresi linear sederhana, yang akan di uji dengan menggunakan Eviews 9 untuk mengetahui bahwa apakah terdapat hubungan linier antara variabel bebas terhadap variabel terikat. Adapun model persamaan regresi yang dapat diperoleh dalam analisis tersebut adalah:

$$
\mathbf{Y}=\mathbf{a}+\mathbf{b X}+\mathbf{e}
$$

Dimana:

$$
\begin{aligned}
& \mathrm{Y}=\text { Laba Bank Umum Syariah } \\
& \mathrm{a}=\text { Konstanta } \\
& \mathrm{b}=\text { Koefisien Regresi } \\
& \mathrm{X}=\text { Pembiayaan Mudharabah }
\end{aligned}
$$

\section{$\mathrm{E}=$ Error Term}

Berikut penjelasan tentang variabel bebas dan variabel terikat pada penelitian ini:

1. Variabel bebas (independen)

$\mathrm{X}=$ Pembiayaan Mudharabah

Pembiayaan mudharabah merupakan suatu akad kerja sama yang dilakukan oleh dua pihaak atau lebih dengan syarat dan ketentuan tertentu yang telah di sepakati oleh pihak yang bersangkutan. Dinyatakan dalam bentuk rupiah (Rp) namun di ubah ke ln dengan ukuran persen (\%).

2. Variabel terikat (dependen)

$\mathrm{Y}=$ Laba

Laba merupakan selisih lebih dari pendapatanpendapatan yang diterima oleh perusahaan setelah dikurangi dengan biaya-biaya yang dikeluarkan oleh perusahaan. Dinyatakan dalam rupiah $(\mathrm{Rp})$ namun di ubah kedalam ln dengan ukuran persen $(\%)$.

\section{HASIL PENELITIAN DAN PEMBAHASAN}

\section{Pertumbuhan Perbankan Syariah dibandingkan dengan Pertumbuhan Perbankan Konvensional}

Pertumbuhan perbankan syariah dibandingkan dengan pertumbuhan perbankan konvensional dilihat dari segi jumlah bank, banyaknya kredit yang disalurkan dan banyaknya tabungan / deposito. Berikut ini tabel Perbandingannya, yaitu:

\section{Tabel 2.}

Perbandingan Pertumbuhan Perbankan Syariah den Pertumbuhan Perbankan Konvensional Tahun 2017

\begin{tabular}{|l|l|l|}
\hline \multicolumn{1}{|c|}{ Perbandingan } & Perbankan Syariah & \multicolumn{1}{c|}{$\begin{array}{c}\text { Perbankan } \\
\text { Konvensional }\end{array}$} \\
\hline Jumlah Bank & 117 & 115 \\
\hline Jumlah kredityang disalurkan & 5.402 .212 & 4.781 .959 \\
\hline Jumlah tabungan / deposito & 25.821 .550 & 127.882 \\
\hline
\end{tabular}

Sumber. Otoritas jasa Keuangan (OJK), 2017

Tabel di atas menjelaskan bahwa Pertumbuhan Perbankan Syariah lebih pesat dibandingkan Perbankan konvensional yang dapat dilihat dari selisih jumlah bank yaitu Perbankan Syariah sebanyak 117 bank dan Perbankan Konvensional sebnyak 115 bank. Jumlah kredit yang disalurkan Perbankan syariah lebih banyak dibanding perbankan konvensional begitu pula dengan jumlah data tabungan masing-masing perbankan. 


\section{Deskripsi Penelitian}

Deskripsi penelitian bertujuan untuk mengetahui gambaran secara umum dari Laba Bank UmumSyariah (BUS) di Indonesia. Berikut adalah hasil olah data yang ditunjukkan tabel 4.1 dibawah ini:

Tabel 3.

Deskripsi Penelitian

\begin{tabular}{|l|c|c|}
\hline & LABA BUS & PEMBIAYAAN_MUDHARABAH \\
\hline Mean & 213.1963 & 2.716247 \\
\hline Median & 214.9483 & 2.906921 \\
\hline Maximum & 219.5627 & 3.319995 \\
\hline Minimum & 205.0779 & 1.921824 \\
\hline Std. Dev. & 7.399611 & 0.718324 \\
\hline Skewness & -0.410584 & -0.453291 \\
\hline Kurtosis & 1.500000 & 1.500000 \\
\hline & & \\
\hline Jarque-Bera & 0.365540 & 0.383986 \\
\hline Probability & 0.832960 & 0.825312 \\
\hline & & \\
\hline Sum & 639.5889 & 8.148740 \\
\hline Sum Sq. Dev. & 109.5085 & 1.031977 \\
\hline & & \\
\hline Observations & 3 & 3 \\
\hline
\end{tabular}

Sumber Output Eviews 9 (Data Diolah), 2018

Tabel 4.2 di atas menjelaskan bahwa nilai ratarata dari variabel Laba Bank Umum syariah (Y) adalah sebesar $213.19 \%$ dan nilai rata-rata dari Pembiayaan Mudharabah $(\mathrm{X})$ adalah sebesar $2.71 \%$. Adapun nilai maksimum Laba Bank Umum Syariah (Y) adalah $219.56 \%$ sedangkan nilai maksimum Pembiayaan Mudharabah (X) adalah sebesar $3.31 \%$. Juga nilai Minimun Laba Bank Umum Syariah adalah 205.07\% dan nilai minimun Pembiayaan Mudharabah adalah $1.92 \%$.

\section{Data Tingkat Pembiayaan Mudharabah dan Laba Bank Umum Syariah (BUS) di Indonesia}

Berikut ini data pembiayaan mudharabah dan laba Bank Umum Syariah (BUS) yang disajikan dalam bentuk grafik.

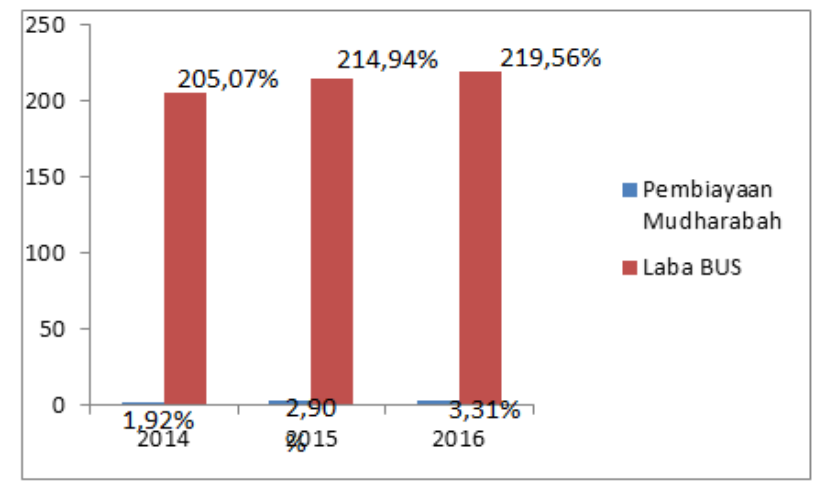

Sumber. Data diolah peneliti 2018

Gambar 2

Data penelitian (Persen)

Dari gambar di atas dapat dilihat bahwa terjadi peningkatan tingkat pembiayaan mudharabah pada tahun 2014 hingga tahun 2016 dari 1,92\% menjadi
3,31\%. Laba Bank Umum Syariah pun terus meningkat dari tahun 2014-2016 dari 205,07\% menjadi 219,56\%

\section{Hasil Penelitian.}

Tabel 4.

Hasil Regresi Variabel

\begin{tabular}{|c|c|c|c|c|}
\hline \multicolumn{5}{|c|}{ Dependent Variable: LABA_BUS } \\
\hline \multicolumn{5}{|c|}{ Method: Least Squares } \\
\hline \multicolumn{5}{|c|}{ Date: $09 / 14 / 18$ Time: $10: 22$} \\
\hline \multicolumn{5}{|c|}{ Sample: 20142016} \\
\hline \multicolumn{5}{|l|}{ Included observations: 3} \\
\hline Variable & Coefficier & 1iStd. Error & t-Statistic & Prob. \\
\hline C & 185.2247 & 0.728302 & 254.3242 & 0.0025 \\
\hline $\begin{array}{l}\text { PEMBIAYAAN_MUDH } \\
\text { ARABAH }\end{array}$ & 10.29789 & 0.262088 & 39.29176 & 0.0162 \\
\hline R-squared & 0.999353 & \multicolumn{2}{|c|}{ Mean dependent var } & 213.1963 \\
\hline Adjusted R-squared & 0.998705 & \multicolumn{2}{|c|}{ S.D. dependent var } & 7.399611 \\
\hline S.E. of regression & 0.266245 & \multicolumn{2}{|c|}{ Akaike info criterion } & 0.425923 \\
\hline Sum squared resid & 0.070887 & \multicolumn{2}{|c|}{ Schwarz criterion } & -0.175002 \\
\hline Log likelihood & 1.361115 & \multirow{2}{*}{\multicolumn{2}{|c|}{$\begin{array}{l}\text { Hannan-Quinn criter. } \\
\text { Durbin-Watson stat }\end{array}$}} & -0.782013 \\
\hline F-statistic & 1543.842 & & & 2.894309 \\
\hline Prob(F-statistic) & 0.016199 & & & \\
\hline
\end{tabular}

Adapun model persamaan regresi yang dapat diperoleh dalam analisis tersebut adalah:

$$
\mathrm{Y}=\mathbf{1 8 5 . 2 2 + 1 0 . 2 9 X}
$$

Dari persamaan regresi tersebuut dapaat diliihat bahwaa besar nilai konstanta adalah 185.22 hal ini berarti jika pembiayaan mudharabah $(\mathrm{X})$ bernilai konstan (0) maka Laba Bank Umum Syariah (Y) nilainya sebesar $185.22 \%$. Koefisien regresi (X) sebesar 10.29 yang berarti bahwa jika Tingkat Pembiayaan Mudharabah (X) meningkat sebesar 1\% maka Laba Bank Umum Syariah (Y) akan meningkat sebesar $10.29 \%$.

\section{Uji Asumsi Klasik \\ Uji Normalitas}

Data dalam penelitian tersebut berdistribusi normal dan sebaliknya jika nilai Probability < Alpha 0.05 Maka data dalam penelitian tersebut tidak berdistribusi normal.

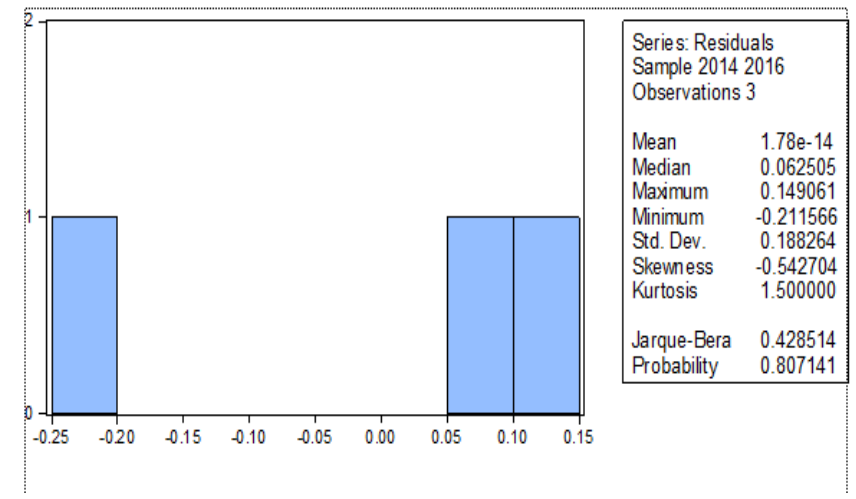

Gambar 3

\section{Uji Normalitas}

Disimpulkan bahwa nilai probability > Alpha 0.05 atau $0.80>0.05$ yang berarti bahwa data dalam penelitian ini sudah terdistribusi dengan normal. 


\section{Uji Autokorelasi}

Metode ini didasarkan pada nilai Probabilitas Chi Square. Dimana jika nilai probabilita Chi Square melebihi tingkat kepercayan berarti tidak ada masalah autokorelasi.

\begin{tabular}{|l|l|l|l|}
\hline Heteroskedasticity Test: Breusch-Pagan-Godfrey & \\
\hline \hline F-statistic & 0.697636 & Prob. F(1,1) & 0.5570 \\
\hline Obs*R-squared & 1.232837 & Prob. Chi-Square(1) & 0.2669 \\
\hline Scaled explained SS & 0.034245 & Prob. Chi-Square(1) & 0.8532 \\
\hline \hline
\end{tabular}

Dari tabel di atas dapat dilihat nilai Prob Chi Square $>0.05$ atau $0.2669>0.05$ yang berarti tidak ada masalah autokorelasi.

\section{Uji Statistik}

\section{Koefisien Determinasi $\left(\mathbf{R}^{2}\right)$}

Nilai R-Square atau $\mathrm{R}^{2}$ adalah 0.99 jadi besarnya pengaruh Pembiayaan Mudharabah (X) terhadap Laba bank Umum Syariah (Y) adalah sebesar $0.99(99 \%)$ sedangkan yang sipengaruhi oleh variabel lain adalah sebesar $0.01(1 \%)$.

\section{Uji Signifikansi Parsial (Uji t)}

Nilai $t$ hhitung $>\mathrm{t}$ tabel atau $-39.291>2.0322$ maka tolak Ho dan terima Ha yang berarti bahwa Pembiayaan Mudharabah (X) berpengaruh secara signifikan dan positif terhadap Laba Bank Umum Syariah (Y). Hal ini juga dapat dilihat dari nilai Prob sebesar $0.0162<0.05$.

\section{KESIMPULAN DAN SARAN}

\section{Kesimpulan}

Berdasarkan hasil analisis data dan pembahasan yang sudah di uraikan dapat di tarik kesimpulan sebagai berikut:

1. Hasil Uji Regresi Linear Sederhana memperlihatkan bahwa secara parsial atau Uji $t$ Pembiayaan Mudharabah (X) berpengaruh signifikan dan negatif terhadap Laba Bank Umum Syariah (BUS) (Y).

2. Besarnya pengaruh Pembiayaan Mudharabah (X) terhadap Laba Bank Umum Syariah (Y) adalah sebesar 0.99 (99\%) sedangkan yang dipengaruhi oleh variabel lain adalah sebesar $1 \%$.

\section{Saran}

Diharapkan pembiayaan mudharabah dapat ditingkatkan agar masyarakat dapat lebih terbantu dengan adanya pembiayaan mudharabah.

\section{DAFTAR PUSTAKA}

Antonio, M.S. (2001). Bank Syariah Dari Teori ke Praktek. Jakarta: Gema Insani

Ismail. (2011). Perbankan Syariah. Jakarta: Kencana.

Karim, A. A. (2004). Bank Islam: Analisis Fiqih dan Keuangan. Jakarta: PT Raja Grafindo Persada.

Kasmir. (2012). Analisis Laporan keuangan. Jakarta: PT Raja Grafindo Persada.

Muhammad. (2005). Konstruksi Mudharabah Dalam Bisnis Syariah. yogyakarta: Penerbit BPFE.

Qordhawi, Y. (1997). Norma dan Etika Ekonomi Islam. Jakarta: Gema Insani Pers

Sanusi, A. (2011). Metodologi Penelitian Bisnis. Jakarta: Salamba Empat

Sudarsono, H. (2007). Bank dal Lembaga Keuangan Syariah: Deskripsi dan Ilustrasi. Yogyakarta: Ekonisia. 